\title{
KESINAMBUNGAN BAHASA IBU DAN LOYALITAS PENUTUR BAHASA MELAYU BETAWI DI SETU BABAKAN: KAJIAN TENTANG PEMERTAHANAN BAHASA
}

\author{
Somadi Sosrohadi ${ }^{1}$,Tadjuddin Nur ${ }^{1}$ \\ ${ }^{1}$ Program Studi Bahasa dan Sastra, Universitas Nasional \\ email : somadi.sosrohadi@civitas.unas.ac.id, tadjuddin.nur@civitas.unas.ac.id
}

Korespondensi : somadi.sosrohadi@civitas.unas.ac.id

\begin{abstract}
This study aims to: 1) Describe the continuity of mother tongue transfer in Setu Babakan. 2) Describe the language loyalty of the Betawi community in Setu Babakan towards their mother tongue. 3) Finding the effect of language loyalty on maintaining mother tongue. This type of research is quantitative-qualitative descriptive (mixed method). Respondents were obtained from a random technique in Betawi Cultural Village in Setu Babakan Jagakarsa, South Jakarta. Language defense is more concerned with how a particular speech community defends its mother tongue. The results of this study: 1) The transfer of mother tongue in Setu Babakan is still awake although not very strong. 2) Language loyalty in the Betawi community in Setu Babakan is positive. 3) Language loyalty has a significant effect on maintaining mother tongue.
\end{abstract}

Keywords: mother tongue, language continuity, speaker loyalty, betawi malay language, language maintenance

\begin{abstract}
Abstrak
Penelitian ini bertujuan untuk: 1) Mendeskripsikan kesinambungan pengalihan bahasa ibu di Setu Babakan .2) Mendeskripsikan loyalitas bahasa masyarakat Betawi di Setu Babakan terhadap bahasa ibu. 3) Menemukan pengaruh loyalitas bahasa terhadap pemertahanan bahasa ibu. Jenis penelitian ini adalah deskriptif kuantitatif-kualitatif (mixed method). Responden diperoleh dari teknik random di Perkampungan Budaya Betawi Setu Babakan Jagakarsa Jakarta Selatan. Pemertahanan bahasa lebih menyangkut bagaimana suatu komunitas tutur tertentu mempertahankan bahasa ibunya. Hasil penelitian ini: 1) Pengalihan bahasa ibu di Setu Babakan masih terjaga walaupun tidak terlalu kuat. 2) Loyalitas bahasa masyarakat Betawi di Setu Babakan positif. 3) Loyalitas bahasa berpengaruh signifikan terhadap pemertahanan bahasa ibu.
\end{abstract}

Kata kunci: bahasa ibu, kesinambungan bahasa, loyalitas penutur, bahasa melayu betawi, pemertahan bahasa 


\section{PENDAHULUAN \\ Latar belakang}

Bahasa Ibu atau bahasa daerah adalah salah satu kekayaan budaya di Indonesia yang perlu dijaga dan dilestarikan, karena bahasa merupakan bagian dari kehidupan masyarakat penuturnya. Bahasa ibu atau bahasa daerah penting untuk terus dipertahankan pemakaiannya karena bahasa daerah maupun bahasa nasional (bahasa Indonesia) memiliki fungsi dan kedudukan masing-masing. Bahasa-bahasa penduduk asli seperti bahasa Jawa, bahasa Sunda, bahasa Bali, bahasa Bugis, bahasa Melayu Betawi, dan sebagainya berkedudukan sebagai bahasa daerah (Chaer dan Agustina, 2010).

Pada umumnya seorang penutur bukan ekabahasawan, melainkan dwibahasawan karena banyak diantara mereka menguasai bahasa lain, meskipun kemampuan itu hanya sekadar mampu berbicara sedikit-sedikit. Penutur asli bahasa ibu memperoleh dan menggunakan bahasa lain karena kebutuhan pragmatis, yaitu demi hubungan pekerjaan atau ekonomi. Dengan demikian, dapat dikatakan bahwa motivasi yang melandasi pemerolehan dan penggunaan bahasa lain adalah motivasi instrumental bukan motivasi integratif. Kondisi seperti itu tentu sangat menguntungkan dalam proses pemertahanan sebuah bahasa. Dikarenakan anak-anak mereka tidak harus menjadi dwibahasawan pada usia muda sehingga pemertahanan bahasa dapat berlanjut. Proses pengalihan bahasa ibu meskipun dilakukan di bawah kesadaran kepada generasi berikutnya, jelas merupakan wujud nyata dari kesetiaan generasi tua terhadap bahasa ibu. Perilaku ini merupakan faktor penting dalam pemertahanan dan pelestarian bahasa itu, sehingga tidak tergeser oleh bahasa mayoritas.

Bahasa sebagai lambang identitas kelompok atau guyub yang memilikinya. Proses pengalihan bahasa ibu kepada generasi berikutnya jelas menggambar kesetiaan generasi tua terhadap bahasanya. Loyalitas atau kesetiaan terhadap bahasa ibu makin jelas manakala penuturnya menjelaskan alasan yang melandasi pengalihan bahasa ibu. Jika generasi tua mengalihkan bahasa ibu kepada generasi muda dengan cara pengungkapan yang berbeda-beda. Hal ini sangat memengaruhi dalam pemertahanan suatu bahasa. Selain itu, generasi muda juga harus memiliki kesadaran yang tinggi terhadap penggunaan bahasa ibu sesuai dengan proporsinya. Artinya, generasi muda harus mengetahui kapan harus menggunakan bahasa ibu dan kapan menggunakan bahasa lain. (Sumarsono dan Pratana, 2002).

Uraian di atas yang menjadi inspirasi dilakukanya penelitian ini. Objek penelitian ini adalah bahasa ibu masyaraktat di Perkampungan Budaya Betawi Setu Babakan, Jagakarsa, Jakarta Selatan. Bahasa ini mempunyai karakteristik tersendiri, baik secara linguistik maupun secara sosial. Sebagai salah satu ragam bahasa Melayu, bahasa Melayu Betawi (BMB) merupakan salah satu mata rantai sebaran bahasa Melayu di Jawa dari Kalimantan Barat. BMB dipakai oleh sebuah guyub masyarakat yang tinggal di wilayah Jakarta dan sekitarnya. 
Sebagai salah satu ragam bahasa Melayu, BMB memang tidak terlalu berbeda dengan bahasa Indonesia yang juga merupakan ragam bahasa Melayu. Hal yang paling menonjol dan menjadi ciri BMB adalah dialek, beberapa unsur linguistik, dan kosa katanya.

Seiring perkembangan ibukota menjadi kota megapolitan penduduk Betawi tergusur ke pinggir-pinggir kota. Derasnya urbanisasi ke ibukota sejak kemerdekaan hingga kini menjadikan banyak penduduk Betawi tidak ada pilihan lain untuk pindah ke pinggir kota. Masyarakat Betawi saat ini hanya tersebar di beberapa wilayah Jakarta, seperti di Cengkareng, Tanah Abang, Rawa Belong, Jagakarsa, Condet, dan Cempaka Putih. BMB hanya digunakan pada sebagian masyarakat di kawasan tersebut.

Perkampungan Setu babakan masih dihuni mayoritas orang Betawi. Setu Babakan merupakan kawasan hunian yang masih memelihara seni budaya dan dijadikan kawasan Pusat Perkampungan Budaya Betawi. Kawasan itu telah dijadikan cagar budaya Betawi berdasarkan Keputusan Gubernur Propinsi DKI Jakarta Nomor 92 Tahun 2000 tentang Penataan Lingkungan Perkampungan Budaya Betawi di Kelurahan Srengseng Sawah Kecamatan Jagakarsa Kotamadya Jakarta Selatan. Fungsi Perkampungan Budaya Betawi sebagaimana tertuang dalam pasal 5 Keputusan tersebut, yaitu : (1) Sebagai sarana informasi, (2) Sarana penelitian dan pengembangan, (3) Sarana seni budaya, (4) Sarana edukatif dan rekreasi, dan (5) Sarana pariwisata.

Perkampungan ini luasnya 165 hektar, 65 hektar diantaranya milik pemerintah. Perkampungan ini didiami setidaknya 3.000 kepala keluarga. Sebagian besar penduduknya adalah orang asli Betawi yang sudah turun temurun tinggal di daerah tersebut. Sebagian kecil penduduk merupakan para pendatang, seperti pendatang dari Jawa Barat, Jawa Tengah, Kalimantan, dan lain-lain. Dengan populasi penduduk mayoritas asli Betawi, apakah bisa menjamin adanya kesinambungan bahasa ibu dan loyalitas masyarakat terhadap bahasa ibu mereka tetap terjaga? Tentu ini harus dijawab dengan suatu penelitian.

Kehawatiran akan melemahnya kesinambungan bahasa ibu dan loyalitas masyarat terhadap bahasa ibu cukup beralasan. Pertama, di tengah gempuran pendatang dari berbagai daerah di Jakarta memengaruhi komunikasi penutur bahasa ibu mereka. Kedua, telah terjadi kawin campur antar suku juga akan memengaruhi penggunaan bahasa ibu mereka. Ketiga, semakin menurunnya orang tua masyarakat Betawi yang mengajarkan atau menurunkan bahasa ibu kepada anak-anaknya. Dari berbagai hal tersebutlah penelitian ini dilakukan untuk menjelaskan apakah kesinambungan bahasa ibu dan loyalitas masyarakat terhadap bahasa ibu mereka masih tetap terjaga terutama di wilayah Perkampungan Budaya Betawi Setu Babakan.

\section{Rumusan Masalah}

Masalah dalam penelitian ini, yaitu:

1. Bagaimana kesinambungan pengalihan bahasa ibu di Perkampungan Budaya Betawi Setu Babakan? 
2. Bagaimana loyalitas masyarakat Betawi terhadap bahasa ibu di Perkampungan Budaya Betawi Setu Babakan?

3. Adakah pengaruh loyalitas bahasa masyarakat Betawi terhadap pemertahanan bahasa ibu di Perkampungan Budaya Betawi Setu Babakan?

\section{Tujuan Penelitian}

Sejalan dengan latar belakang dan rumusan masalah, maka tujuan penelitian ini adalah sebagai berikut :

1. Mendeskripsikan kesinambungan pengalihan bahasa ibu di Perkampungan Budaya Betawi Setu Babakan.

2. Mendeskripsikan loyalitas bahasa masyarakar terhadap bahasa ibu di Perkampungan Budaya Beawi Setu Babakan.

3. Menemukan pengaruh loyalitas bahasa masyarakat terhadap pemertahanan bahasa ibu.

\section{LANDASAN TEORI}

Memahami perihal kepunahan bahasa berkaitan dengan konsep pergeseran bahasa ialah bahwa dalam konsep pergeseran bahasa ini dikatakan mengalami pergeseran jika pemakaian antara bahasa ibu dan bahasa lain tidak seimbang. Ketika keseimbangan ini tidak ada lagi, dua kemungkinan yang akan muncul. Kemungkinan yang pertama adalah bahasa ibu tetap bertahan, kedua bahasa ibu tersingkirkan oleh bahasa lain. Dari kedua kemungkinan ini, yang mengarah kepada kepunahan adalah kemungkinan kedua yaitu bahasa ibu tersingkirkan oleh bahasa lain.

Bagaimana kemungkinan ini bisa terjadi? Untuk menjawab hal ini, mari kita cermati kasus Fischer (2001). Pada kasus yang ditemukan oleh Fischer dinyatakan, masyarakat monolingual yang menguasai bahasa ibunya kembali menjadi masyarakat monolingual yang menguasai bahasa lain. Apabila kasusnya seperti ini katakanlah bahasa ibu yang pada mulanya dipakai oleh suatu guyub tutur menjadi punah karena guyub tutur tersebut lebih mengutakan bahasa lain.

Menurut Fasold (1984) pemertahanan bahasa adalah hasil dari proses pemilihan bahasa dalam jangka waktu yang sangat panjang. Pemertahanan bahasa lebih menyangkut bagaimana suatu komunitas tutur tertentu mempertahankan bahasa ibunya. Pemertahanan bahasa juga berkaitan dengan masalah sikap atau penilaian terhadap suatu bahasa untuk tetap digunakan di tengah-tengah bahasabahasa lainnya. Dalam lingkungan yang plural, penutur akan cenderung memilih bahasa yang dianggap tepat untuk memahami situasi komunikasi di tempat mereka tinggal.

Menurut Fishman (1972), aktivitas komunikasi bergantung pada lokasi, topik, dan partisipan. (Fishman, 1972; Hymes, 1967) menyatakan bertahan atau tidaknya bahasa suatu komunitas tutur memunculkan adanya peristiwa pergeseran bahasa (language shift).

Lieberson (1972) menyatakan bahwa hampir semua kasus pergeseran bahasa dalam masyarakat terjadi melalui peralihan antargenerasi dalam satu 
masyarakat dwibahasa. Namun, ada juga masyarakat dwibahasa yang dapat tetap mempertahankan bahasanya selama berabad-abad.

Fishman (1972) dalam kajiannya menyatakan, bahwa pemertahanan bahasa terjadi tidak semata-mata karena kesetiaan yang tinggi atau perasaan yang kuat terhadap nasionalisme dalam suatu kelompok. Pada masyarakat desa, pemertahanan bahasa cenderung tinggi atau tidak mengalami pergeseran karena faktor-faktor lain. Pada kasus pergeseran bahasa, tidak berarti juga, bahwa bahasa dengan prestise yang tinggi dapat menggantikan bahasa dengan prestise yang rendah sedangkan dilihat dari sisi gender, tingkat pergeseran bahasa, baik pada perempuan maupun lelaki juga bisa jadi rendah atau tinggi karena faktor-faktor tertentu. Dari kasuskasus yang ada, Mesthrie mengutip Giles et al. 1977; (Appel dan Muysken, 1987) merangkum faktor-faktor penyebab pergeseran bahasa, seperti perubahan kondisi ekonomi, status, demografi, dan dukungan institusional.

Faktor apa sebenarnya yang menyebabkan pemertahanan bahasa itu terjadi. Banyak teori, yang didasarkan atas hasil-hasil penelitian. Salah satunya Fishman (1966) mengatakan bahwa loyalitas bahasa merupakan faktor penting dalam pemertahanan bahasa, setidak-tidaknya dalam kondisi Amerika yang memiliki banyak minoritas, dan loyalitas itu berakar pada asal-usul seseorang. Sikap loyal itu, sebagaimana sikap pada umumnya, dapat merupakan sesuatu yang tidak dapat diamati, tetapi karakteristiknya dapat disimpulkan dari tingkah laku yang dapat diamati. Sikap bahasa dapat bersifat positif atau bersifat negatif. Jika masyakat tutur masih sangat bergairah untuk menggunakan bahasa ibunya itu artinya masyarakat tersebut bersifat positif terhadap bahasanya. Sebaliknya jika masyarakat tutur tidak lagi memiliki gairah untuk mempertahankan bahasanya atau tidak lagi bangga terhadap bahasanya, maka mereka sudah bersifat negatif terhadap bahasanya.

Sikap bahasa, sebagaimana diungkapkan Garvin (1968) setidak-tidaknya mengandung tiga ciri pokok, yaitu kesetiaan bahasa (language loyalty), kebanggaan bahasa (language pride), dan kesadaran akan norma bahasa (awareness of the norm). Ketiga ciri sikap bahasa tersebut merupakan ciri sikap positif terhadap bahasa. Akan tetapi, jika sikap positif tersebut sudah tidak ada atau melemah maka seseorang atau sekelompok masyarakat tutur sudah dilanda oleh sikap negatif terhadap bahasanya. Loyalitas bahasa (language loyalty) yang mendorong masyarakat suatu bahasa mempertahankan bahasanya dan apabila perlu mencegah adanya pengaruh bahasa lain. Tidak adanya dorongan untuk mempertahankan kemandirian bahasanya menandakan, bahwa loyalitas berbahasa masyarakat tersebut lemah. Loyalitas bahasa menurut Garvin inilah yang dijadikan tuntutan dalam menentukan loyalitas bahasa masyarakat Betawi Setu Babakan terhadap bahasa ibu dalam penelitian ini.

Sedangkan Lambert (1976) menyatakan bahwa sikap itu terdiri dari tiga komponen, yaitu komponen kognitif, komponen afektif, dan komponen konatif. Komponen kognitif berhubungan dengan pengetahuan mengenai alam sekitar dan gagasan yang biasanya merupakan kategori yang digunakan dalam proses berpikir.

Sesungguhnya pendapat Garvin (1968) dan Lambert (1976) tentang sikap bahasa memiliki kesamaan. Kesetian bahasa (language loyalty) yang dikemukakan oleh Garvin diungkapkan oleh Lambert sebagai aspek kognitif. 


\section{METODE PENELITIAN}

Penelitian ini menggunakan pendekatan sosiolinguistik, yaitu suatu pendekatan yang mengkaji bahasa dalam kaitannya dengan masyarakat. Jenis penelitian yang digunakan dalam penelitian ini adalah metode campuran (mixed method) yaitu gabungan antara metode kuantitatif dengan metode kualitatif dengan strategi campuran penguatan (Concurrent Embedded Strategy), yaitu kualitatif menjadi metode primer dan kuantitatif menjadi metode skunder. Metode kualitatif untuk menemukan pengalihan nahasa ibu dan loyalitas bahasa masyarakat terhadap bahasa ibu sementara metode kuantitaif untuk menguji pengaruh loyalitas bahasa terhadap pemertahanan bahasa ibu. Data dikumpulkan menggunakan kuesioner secara bersamaan antara data kualitaif dan data kuantitatif.

\section{HASIL DAN PEMBAHASAN}

\section{Pengalihan Bahasa Ibu}

Pengalihan bahasa ibu terlihat dari bahasa yang diajarkan orang tua kepada anak-anaknya. Bahasa yang diajarkan orangtua kepada anak-anaknya di Setu Babakan pada setiap generasi dapat dilihat pada gambar 3.

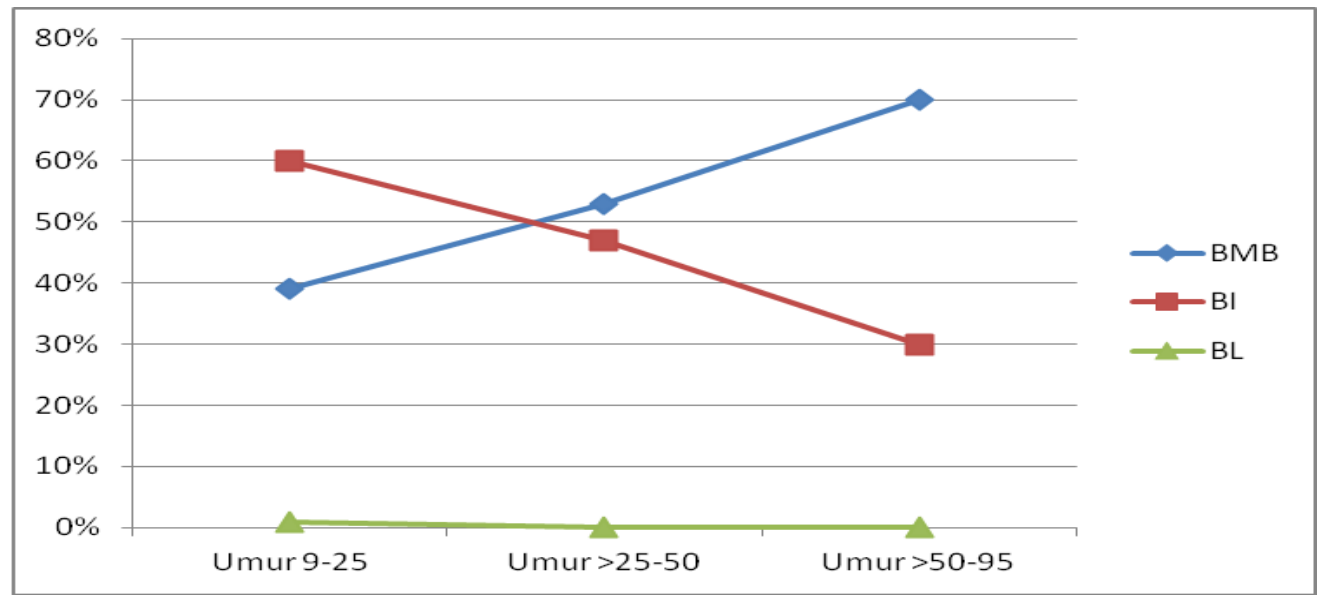

Gambar 3. Pengalihan bahasa ibu

Gambar di atas menunjukkan tentang pengalihan bahasa, yaitu bahasa yang diajarkan orang tua kepada anak-anaknya dalam tiga generasi. Pada kelompok umur 9 - 25 tahun (kelompok 1) pengalihan bahasa Indonesia (BI) lebih kuat dibandingkan dengan bahasa Melayu Betawi (BMB) dan bahasa lain (BL). Pada kelompok umur 25- 50 tahun (kelompok 2) pengalihan BMB lebih kuat sedikit dibandingkan dengan pengalihan BI, sementara untuk BL rendah. Pada kelompok umur 50 - 95 tahun (kelompok 3) pengalihan BMB lebih kuat dari BI dan BL. Untuk pengalihan BI kelopok 1 terjadi penurunan dari setiap kelompok umur. Untuk 
pengalihan BMB terjadi peningkatan pada setiap kelompok umur, sementara untuk pengalihan BL tetap rendah.

Bahasa ibu adalah bahasa yang pertama dikenalkan orang tua kepada anakanaknya. Berdasarkan pengakuan responden terhadap bahasa ibu dapat dilihat pada gambar 4.

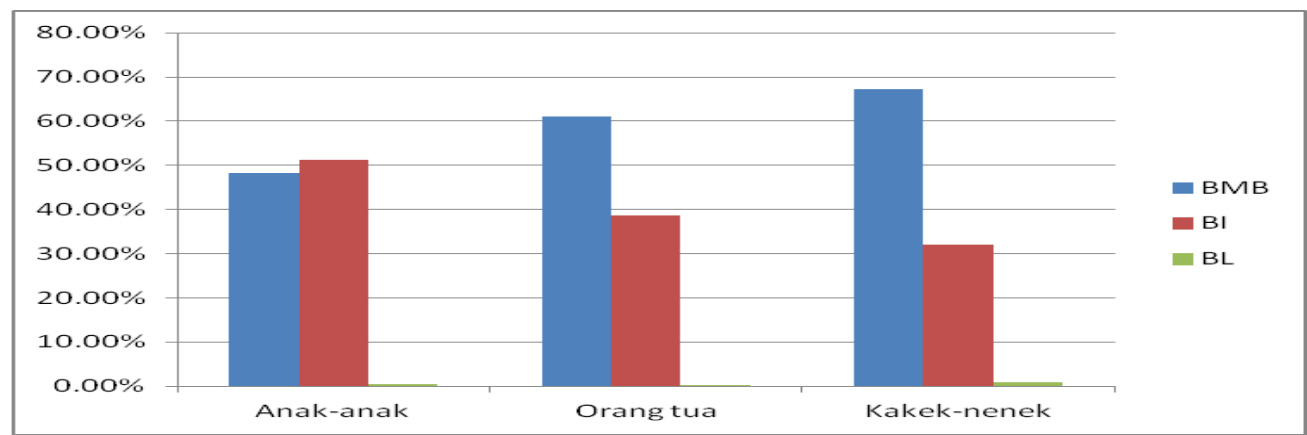

Gambar 4. Bahasa ibu anak, orang tua, dan kakek-nenek

Gambar di atas menjelaskan tentang bahasa yang pertama diterima responden ketika sebagai anak, orang tua mereka, dan kakek-nenek mereka. Dijelaskan bahwa bahasa pertama yang diterima responden ketika sebagai anak adalah untuk BMB $49 \%$, BI 50\%, dan BL di bawah 1\%. Bahasa pertama yang diterima orang tua mereka adalah untuk BMB $61 \%$, BI $38 \%$, dan BL di bawah $1 \%$. Bahasa pertama yang diterima kakek-nenek mereka adalah untuk BMB $68 \%$, BI $31 \%$, dan BL di bawah $1 \%$.

Kepada responden (orang tua) ditanyakan bahasa apa yang diturunkan kepada anak-anaknya? Kepada responden (anak-anak) ditanyakan bahasa apa yang diturunkan oleh orang tuanya serta bahasa apa yang mereka kuasai saat ini? Pengalihan bahasa orang tua kepada anaknya dan bahasa yang diterima anak dari orang tuanya dapat dilihat pada gambar 5 .

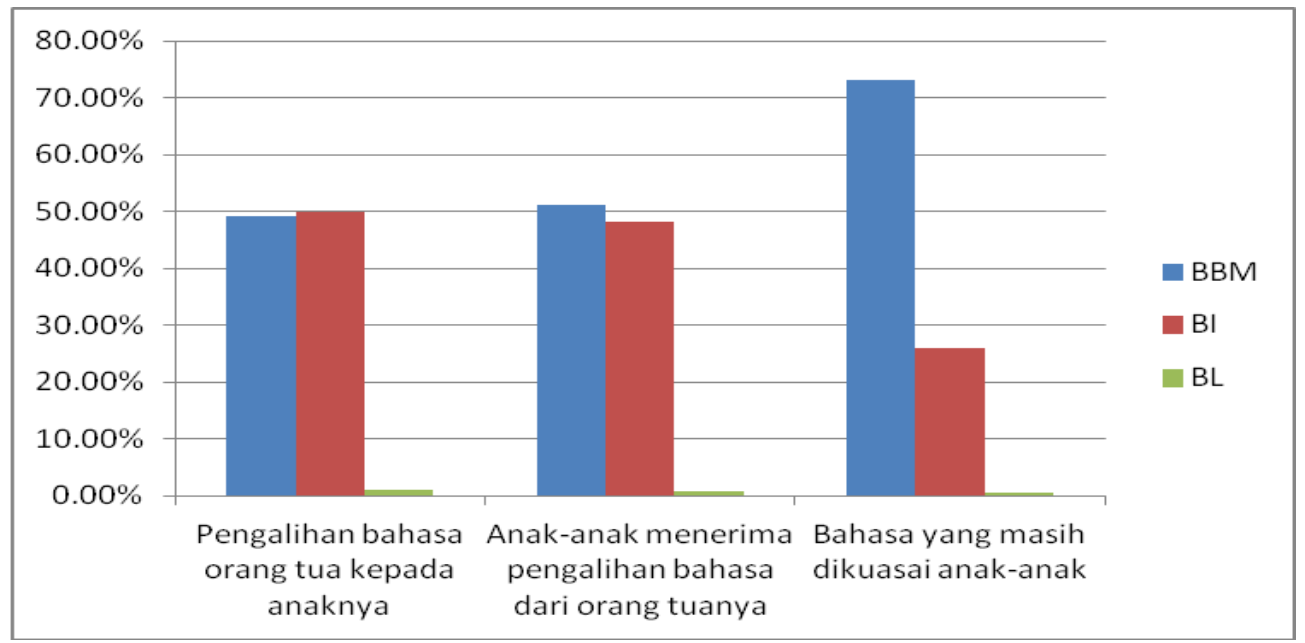




\section{Gambar 5. Pengalihan bahasa dan penguasaan bahasa anak-anak}

Gambar di atas menunjukkan tentang pengalihan bahasa yang dilakukan orang tua kepada anak-anaknya, anak-anak menerima bahasa dari orang tuanya, dan penguasaan bahasa anak saat ini. Pengalihan BMB dan BI dari orang tua kepada anak-anaknya sama kuatnya, sementara BL rendah. Untuk anak-anak yang menerima pengalihan bahasa dari orang tuanya, untuk BMB dan BI juga sama kuat, sementara BL rendah. Namun, penguasaan bahasa anak-anak untuk BMB jauh lebih kuat dari BI dan BL.

Kesinambungan pengalihan bahasa ibu di perkampungan budaya Betawi Setu Babakan masih terpelihara, meskipun tidak terlalu kuat. Pada kelompok 1 pengalihan BI lebih kuat dibandingkan dengan BMB dan BL. Pada kelompok 2 pengalihan $\mathrm{BMB}$ lebih kuat sedikit dibandingkan dengan pengalihan BI, sementara untuk BL rendah. Pada kelompok 3 pengalihan BMB jauh lebih kuat dari BI dan BL. Mencermati pergerakan pengalihan BMB pada setiap kelompok umur, pada kelopok 2 dan 3 pengalihan BMB cukup kuat. Namun, untuk kelompok 1 pengalihan BMB rendah. Untuk pengalihan BI hanya kelompok 1 yang kuat, selebihnya untuk kelompok 2 dan 3 rendah. Sementara untuk pengalihan BL semua kelompok umur rendah.

Kondisi tersebut membuktikan bahwa pengalihan bahasa ibu pada masyarakat Betawi Setu Babakan masih terpelihara, terutama untuk kelopok 2 dan kelompok 3. Namun, untuk kelompok 1 pengalihan bahasa Indonesia lebih dominan. Hal ini membuktikan ada penurunan pengalihan bahasa ibu pada kelompok 1.

Untuk membuktikan menguatnya faktor pengalihan bahasa menjadi salah satu penyebab pemertahanan bahasa ibu di Setu Babakan adalah waktu dan tempat responden menerima bahasa ibu. Responden dominan menerima bahasa ibu sejak lahir sampai umur 10 tahun sebanyak 98,7\% dan mereka mengaku menerima bahasa ibu di rumah sebanyak $90 \%$ dan sisanya $10 \%$ di luar rumah.

Menarik untuk dikaji data tentang orang tua yang menurunkan bahasa ibu kepada anaknya yang relatif rendah. Sementara anak-anak yang menerima bahasa ibu dari orang tuanya ada peningkatan. Menariknya penguasaan bahasa ibu anakanak tinggi. Orang tua yang menurunkan atau mengajarkan bahasa ibu kepada anakanak mereka sebanyak 49,1\%, sementara pengakuan anak-anak yang diturunkan atau diajarkan bahasa ibu oleh orang tuannya 51,2\%. Menariknya penguasaan bahasa ibu anak-anak mencapai 73,4\%. Hal tersebut memberikan gambaran bahwa meskipun pengalihan atau pengajaran bahasa ibu rendah, namun penguasaan bahasa ibu bisa saja tinggi. Pengalihan atau pengajaran bahasa ibu tidak selamanya sebanding dengan penguasaan bahas ibu pada anak-anak, karena penguasaan bahasa ibu tidak hanya didapat pada proses pengalihan bahasa dari orang tua kepada anakanaknya, namun bisa saja didapat dari interaksi antar teman dan interaksi pada lingkungan.

Pengalihan atau pengajaran BI cukup tinggi. Orang tua yang mengalihkan BI kepada anak-anaknya sebanyak 49,9\%, lebih tinggi dari pengalihan bahasa ibu. Anak-anak yang mendapat pengalihan BI dari orang tuanya sebanyak 48,1\%, lebih 
rendah dari pengalihan bahasa ibu. Sementara anak-anak yang menguasai BI hanya $26,1 \%$, jauh lebih rendah jika dibandingkan penguasaan bahasa ibu. Untuk bahasa lainnya, baik bahasa daerah lain maupun bahasa asing sangat rendah dalam pengalihan bahasa maupun penguasaan bahasa anak-anak. Hal tersebut membuktikan BI cukup berpengaruh terhadap penggunaan bahasa percakapan sehari-hari dan berpotensi untuk menggeser bahasa ibu.

Bahasa ibu adalah bahasa yang pertama dikenalkan orang tua kepada anakanaknya. BMB sebagai bahasa ibu masyarakat Betawi di Setu babakan masih cukup kuat. BMB sebagai bahasa ibu generasi kakek-nenek masih kuat, sebanyak 67\%, generasi orang tua juga masih kuat, sebanyak $61 \%$, tetapi menurun di generasi anakanak, sebanyak $48 \%$.

Berdasarkan analisis pengalihan bahasa di atas terungkap bahwa faktor pengalihan bahasa ibu merupakan salah satu penyebab bertahannya bahasa ibu di Setu Babakan, Jagakarsa, Jakarta Selatan. Walaupun tidak terlalu kuat namun pengalihan bahasa ibu masih terjadi di masyarakat. Hasil analisis juga mengungkap BMB sebagai bahasa ibu masih kuat di berbagai generasi meskipun menurun pada generasi anak-anak.

\section{Loyalitas Bahasa}

Loyalitas bahasa terlihat dari sikap responden terhadap bahasanya. Beberapa identifikasi sikap masyarakat terhadap loyalitas bahasa, yaitu sikap mengoreksi jika ada penggunaan BMB yang salah, sikap mencegah pengaruhnya bahasa lain, dan sikap perlunya BMB untuk dilestarikan. Sikap loyalitas bahasa responden dapat dilihat pada gambar 6 .

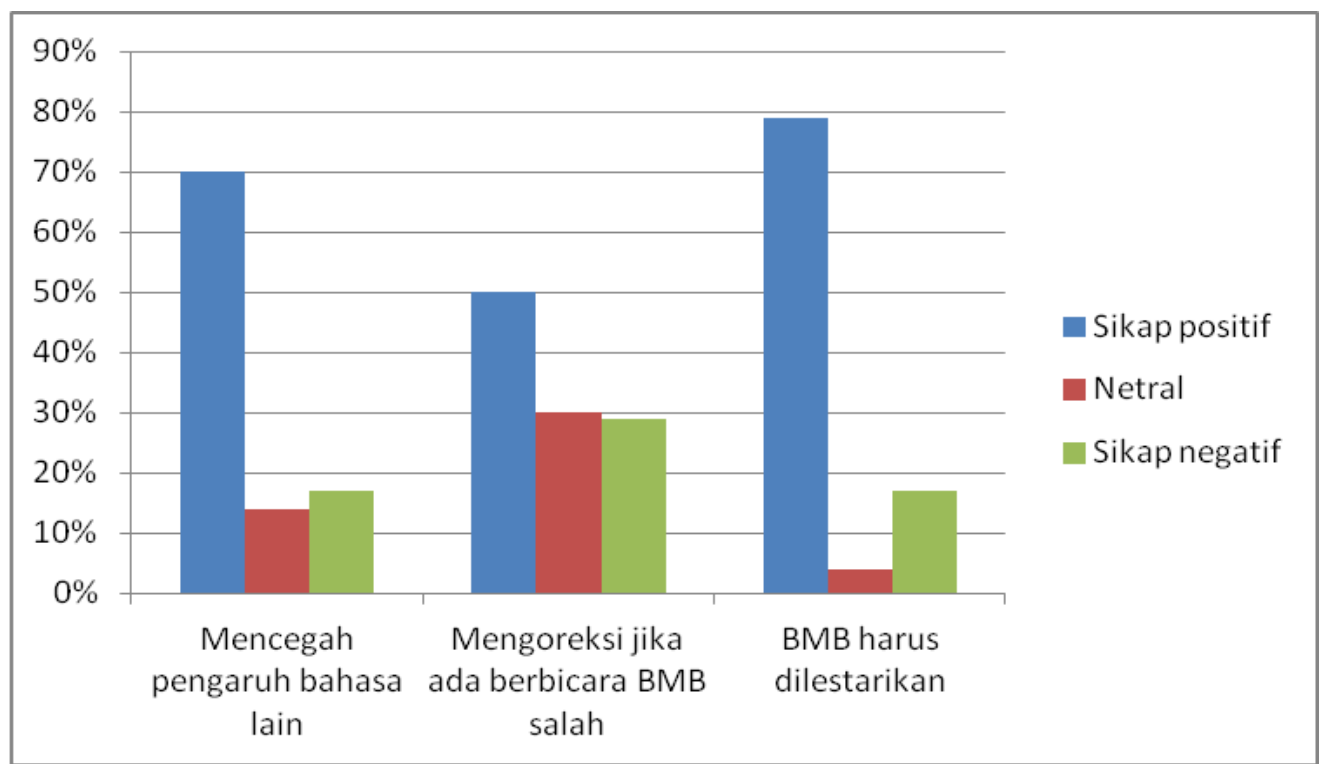

Gambar 6. Sikap loyalitas bahasa responden terhadap bahasa ibu 
Gambar di atas menjelaskan tentang sikap loyalitas bahasa responden terhadap bahasa ibu. Sikap loyalitas bahasa responden untuk mencegah pengaruh bahasa lain terhadap bahasa ibu positif mencapai 70\%. Sikap loyalitas bahasa responden untuk mengoreksi jika ada penggunaan bahasa ibu yang salah juga positif mencapai 50\%. Sikap loyalitas bahasa responden terhadap perlunya pelestarian bahasa ibu positif mencapai $79 \%$. Semua faktor sikap loyalitas bahasa masyarakat Betawi di Setu babakan terhadap bahasa ibu positif.

Fishman (1966) mengatakan bahwa loyalitas bahasa merupakan faktor penting dalam pemertahanan bahasa, setidak-tidaknya dalam kondisi Amerika yang memiliki banyak masyarakat minoritas, dan loyalitas itu berakar pada asal-usul seseorang. Sikap loyal itu, sebagaimana sikap pada umumnya, merupakan sesuatu yang tidak dapat diamati, tetapi karakteristiknya dapat disimpulkan dari tingkah laku yang dapat diamati, sebagaimana pendapat Garvin (1970) tentang loyalitas bahasa (language loyalty), yaitu mendorong masyarakat suatu bahasa mempertahankan bahasanya dan apabila perlu mencegah adanya pengaruh bahasa lain.

Loyalitas bahasa juga mendorong masyarakat untuk mengupayakan pemertahan bahasanya dan jika perlu menolak pengaruh bahasa lain. Hasil analisis seperti terlihat pada gambar 4, responden bersikap untuk mempertahankan bahasanya positif sebesar $79 \%$. Mereka dominan positif mengatakan bahasa ibu perlu dilestarikan, sebesar $79 \%$ dan hanya $17 \%$ dari mereka yang menyatakan bahasa ibu tidak perlu dipertahankan. Sebagian besar, sekiar $70 \%$ lebih mereka juga berpendapat menolak bahasa lain memengaruhi bahasa ibu, hanya $17 \%$ dari mereka yang beranpangan bahasa lain boleh memengaruhi bahasa ibu. Sementara terhadap orang yang salah menggunakan bahasa ibu dalam percakapan sehari-hari, masyarakat yang berpendapat untuk memperbaiki 50\%, dan sebanyak $20 \%$ menyatakan tidak perlu memperbaiki. Hal tersebut membuktikan loyalitas bahasa masyarakat Betawi dalam hal berupaya mempertahankan bahasa ibu, berpandangan perlunya melestarikan bahasa ibu, dan mendorong perbaikan terhadap penggunaan bahasa ibu yang salah sangat positif.

Berdasarkan analisis data di atas terungkap bahwa loyalitas bahasa juga menjadi salah satu penyebab pemertahanan bahasa ibu di Setu Babakan, Jagakarsa, Jakarta Selatan. Sejalan dengan teori Fishman tentang faktor penting pemertahanan bahasa adalah loyalitas, maka pemertahanan bahasa ibu di Setu Babakan akan tetap terjaga setidaknya sampai dua periode ke depan. Hal tersebut dapat dibuktikan dengan data-data masyarakat Betawi di Setu Babakan, khususnya masyarakat kelompok 3 dan kelompok 2 yang loyalitas terhadap bahasa ibu tinggi.

\section{Pengaruh Loyalitas Bahasa Terhadap Pemertahanan Bahasa Ibu}

Sejauh mana pengaruh loyalitas bahasa terhadap pemertahanan bahasa ibu di Setu Babakan terlihat pada tabel di bawah ini: 
Tabel 2: Pengaruh loyalitas bahasa terhadap pemertahanan bahasa ibu

\section{Coefficients $^{\mathrm{a}}$}

\begin{tabular}{|c|c|c|c|c|c|}
\hline \multirow[b]{2}{*}{ Model } & \multicolumn{2}{|c|}{$\begin{array}{l}\text { Unstandardized } \\
\text { Coefficients }\end{array}$} & $\begin{array}{l}\text { Standardiz } \\
\text { ed } \\
\text { Coefficients }\end{array}$ & \multirow[b]{2}{*}{ t } & \multirow[b]{2}{*}{ Sig. } \\
\hline & B & $\begin{array}{l}\text { B Std. } \\
\text { Error }\end{array}$ & & & \\
\hline (Constant) & ,319 &, 116 & & 2,750 & 006 \\
\hline Loyalitas Bahasa &, 156 & 051 & , 191 & 3,400 & 003 \\
\hline
\end{tabular}

Dependent Variable: Pemertahanan Bahasa Melayu Betawi

Hasil pengujian regresi menunjukkan variabel loyalitas bahasa (X1) memperoleh nilai nilai Sig. (Signifikansi) sebesar 0,003 < 0,05. Artinya, variabel loyalitas bahasa (X1) memiliki pengaruh signifikan terhadap variabel pemertahanan bahasa ibu (Y).

Variabel loyalitas bahasa (language loyalty) mendorong masyarakat suatu bahasa mempertahankan bahasanya dan apabila perlu mencegah adanya pengaruh bahasa lain. Hasil uji-t membuktikan variabel loyalitas bahasa (X1) memperoleh nilai $t 3,400$, artinya kesetian bahasa berpengaruh positif terhadap pemertahanan bahasa ibu sebesar 3,400.

Berdasarkan hasil uji di atas dapat disimpulkan bahwa Loyalitas bahasa masyarakat Betawi di Setu Babakan terhadap bahasa ibu masih kuat dan berpengaruh signifikan.

\section{SIMPULAN DAN SARAN}

\section{Simpulan}

Berdasarkan hasil penelitian dan pembahasan yang telah dipaparkan dapat disimpulkan, bahwa:

1. Pengalihan bahasa ibu masyarakat Betawi di Setu Babakan masih berlangsung walaupun tidak terlalu kuat.

2. Loyalitas bahasa masyarakat Betawi di Setu babakan terhadap bahasa ibu positif, baik dalam hal berupaya mempertahankan bahasa ibu, berpandangan perlunya melestarikan bahasa ibu, dan mendorong perbaikan terhadap penggunaan bahasa ibu yang salah sangat positif.

3. Terdapat pengaruh siginifikan loyalitas bahasa masyarakat Betawi di Setu Babakan terhadap bahasa ibu.

\section{Saran}

Saran yang bisa disampaikan pada bagian ini, yaitu : 
1. Kepada Pemerintah Provinsi DKI Jakarta untuk lebih konkret melakukan perencanaan secara sistematis dan pelaksanaan program pembinaan bahasa ibu terutama terhadap masyarakat kelompok umur 25 tahun ke bawah (usia sekolah) dengan cara memasukkan pengenalan bahasa Melayu Betawi dalam kurikulum muatan lokal di sekolah.

2. Kepada masyarakat Betawi dan organisasi masyarakat yang peduli terhadap budaya Betawi untuk melakukan upaya untuk menurunkan bahasa ibu kepada generasi muda Betawi.

\section{DAFTAR PUSTAKA}

Appel, R \& Muysken, P. (1987). Language Contact and Bilingualism. London: Edward Arnold.

Appel, René \& Muysken, Pieter. (2006). Language Contact and Bilingualism. Bibliovault OAI Repository, The University of Chicago Press. 72. $10.2307 / 327522$.

Chaer A. dan Agustina L. (2010). Sosiolinguistik Perkenalan Awal. Jakarta: Rineka Cipta.

Fasold, R. (1984). Sociolinguistics of society. Basil Blackwell Inc., New York

Fishman, J.A. (1972). Language Maintenance and Language Change dalam J.A Fishman, Language in the Sociocultural Change. Standford University Press

Fishman, Joshua A. (1972). Reading in The Sociology Of Language. The Hague: Mouton

Fischer, MH. (2001). Probing spatial working memory with the Corsi blocks task. Brain and Cognition, 45(2), 143-154.Cross Ref Google Scholar Pub Med.

Hymes. (1967). Social Research Why Linguistics Needs the Sociologist by Dell Hymes Published in Social Research. Vol. 34, No. 4 Winter 1967. Pages 632-647

Garvin, P.L. \& Mathiot, M. (1968). The Urbanization of the Guarani Language: A Problem in Language and Culture. In Readings in the Sociology of Language (pp. 365-374).

Garvin, P.L.(ed). (1970). Method and Theory in Linguistics. (Janua Linguarum, Series Maior, 40). The Hague, Mouton. 
Giles, H., Bourhis, R.Y. \& Taylor, D.M. (1997). Towards a theory of language in ethnic group relations. In $H$. Giles $(E d)$. Language. Ethnicity and Intergroup Relations. (pp.307-348). London, UK: Academic Press.

Lambert, K. (1976). Resistance and Counter-Resistance. Journal of Analytical Psychology, 21: 164-192. https://doi.org/10.1111/j.1465-5922.1976.00164.x

Lieberson, Stanley. (1972). Bilingualism in Montreal: a Demografic Analysis, dalam J. Fishman (ed). Advances in the Siciology of Languge jilid 2, The Hague: Mouton.

Lieberson, S., \& O'Connor, J. F. (1972). Leadership and organizational performance: A study of large corporations. American Sociological Review, 37(2), 117-130. https://doi.org/10.2307/2094020.

Paul L Garvin (ed). (1970). Method and Theory in Linguistics. (Janua Linguarum, Seriues Maior, 40). The Hague, Mouton.

Sumarsono dan Partana Paina. (2002). Sosiolinguitik. Yogyakarta: SABDA dan Pustaka Pelajar.

Keputusan Gubernur Propinsi DKI Jakarta Nomor 92 Tahun 2000 tentang Penataan Lingkungan Perkampungan Budaya Betawi 